\title{
The Administration of Garlic Extract on Eimeria stiedai Oocysts and the Hematological Profile of the Coccidia Infected Rabbits
}

\author{
D. Indrasanti*, M. Indradji, S. Hastuti, E. Aprilliyani, Fatikha, \& K. A. Rosyadi \\ Animal Health Laboratory, Faculty of Animal Sciences, Jenderal Soedirman University \\ Jalan Dr. Soeparno 60, Karangwangkal, Purwokerto 53123, Indonesia \\ (Received 11-09-2017; Reviewed 23-10-2017; Accepted 21-11-2017)
}

\begin{abstract}
This research aimed to examine the potential of garlic as the coccidiosis control in rabbits either in vitro or in vivo. During in vitro, observed variables were rabbits oocysts that were sporulated, unsporulated, and abnormal in incubation for 3 days with the addition of garlic extract. The treatments were doses of garlic extract administration $(0 \%, 1 \%, 2 \%, 4 \%$, and $8 \%)$ and sulfaquinoxalline as a standard anticoccidiosis. Meanwhile during in vivo, the variables observed were the hematological profile of the experimental rabbits naturally infected with coccidia. The doses of garlic extract was administered orally to the experimental rabbits infected with coccidia were $0 \mathrm{mg}, 10 \mathrm{mg}, 20 \mathrm{mg}$, $40 \mathrm{mg}$, and $80 \mathrm{mg} /$ rabbit. As a standard coccidiosis drugs, the combination of sulfadiazine and trimethoprim was used. The treatments were given for 6 days. The variables observed were the hematological profile of the coccidiosis rabbits, including the erythrocytes, hemoglobin, hematocrits, $\mathrm{MCV}, \mathrm{MCH}, \mathrm{MCHC}$, and thrombocytes. The research employed a completely randomized design, with 5 repetitions. The data were further analyzed using the honestly significant difference test. The results showed that garlic extract administration significantly decreased $(\mathrm{P}<0.01)$ both the number of the sporulated and unsporulated oocysts $(\mathrm{P}<0.05)$, yet did not significantly influence the abnormal oocysts, but there was no significant difference within the entire hematological variables except in thrombocytes $(\mathrm{P}<0.05)$. Garlic extract administration decreased the excretion number of oocysts in the feces either in vitro or in vivo and influenced some hematological variables which provided a new propect for controlling coccidiosis naturally in rabbits.
\end{abstract}

Keywords: coccidia, rabbits, garlic extract, oocyst, hematology

\section{ABSTRAK}

Penelitian ini bertujuan untuk menguji potensi bawang putih sebagai anti koksidiosis pada kelinci secara in vitro dan in vivo. Secara in vitro, peubah yang diamati adalah ookista kelinci yang bersporulasi, tidak bersporulasi, dan abnormal pada inkubasi selama 3 hari dengan penambahan ekstrak bawang putih. Perlakuan yang digunakan adalah $0 \%, 1 \%, 2 \%$, $4 \%$, dan $8 \%$ bawang putih, serta penggunaan sulfaquinoxalline sebagai obat standar koksidiosis. Pada penelitian in vivo, peubah yang diamati adalah profil hematologi kelinci yang terinfeksi koksidia secara alami. Ekstrak bawang putih diberikan secara per oral pada kelinci yang terinfeksi koksidia sebesar $0 \mathrm{mg}, 10 \mathrm{mg}$, $20 \mathrm{mg}$, $40 \mathrm{mg}$, dan $80 \mathrm{mg} / \mathrm{ekor}$, serta kombinasi sulfadiazin dan trimethoprim sebagai obat standar koksidiosis. Perlakuan diberikan selama 6 hari. Peubah yang diamati adalah profil darah kelinci koksidiosis yang meliputi sel darah merah (eritrosit), hemoglobin (Hb), hematokrit, $\mathrm{MCV}, \mathrm{MCH}, \mathrm{MCHC}$, dan trombosit. Rancangan yang digunakan adalah rancangan acak lengkap (RAL), dengan pengulangan sebanyak 5 kali. Analisis data menggunakan analisis variansi dengan uji lanjut beda nyata jujur (BNJ). Hasil analisis varians menunjukkan bahwa pemberian ekstrak bawang putih berpengaruh sangat nyata menurunkan $(\mathrm{P}<0,01)$ jumlah ookista yang bersporulasi, berpengaruh nyata pada ookista yang tidak bersporulasi $(\mathbf{P}<0,05)$, namun tidak berpengaruh nyata pada ookista yang abnormal. Hasil analisis statistik menunjukkan hasil yang tidak berbeda nyata pada semua peubah hematologi, kecuali trombosit $(P<0,05)$. Pemberian ekstrak bawang putih dapat menurunkan jumlah ekskresi ookista dalam feses secara in vitro dan in vivo dan mempengaruhi beberapa peubah hematologi sehingga memberikan harapan baru bagi pengendalian koksidiosis secara alami pada kelinci.

Kata kunci: koksidia, kelinci, ekstrak bawang putih, ookista, hematologi

${ }^{*}$ Corresponding author:

E-mail: dianaindrasanti@gmail.com 


\section{INTRODUCTION}

Rabbit is one of potential livestock commodities for alternative meat supplies beside as a pet and a laboratory animal. Rabbit meat has a highly nutritious protein content, low fat and cholesterol, rich of calcium and phosphorus, as well as high linoleic acid. Rabbit meat is healthier for human consumption than chicken, beef, and pork due to its high protein and low fat contents (Nistor, et al., 2013). Coccidiosis is an infection caused by Eimeria spp protozoa and this infection and disease is considered as a major obstacle in raising rabbits. Coccidiosis in rabbits may be caused by 11 species of Eimeria spp. in which 10 species may invade the digestive tract and 1 species may invade the liver (Pakandl, 2009). Coccidiosis is associated with anorexia, decreased feed intake and feed utilization, anemia, dehydration, and diarrhea (Abbas et al, 2010; Srinivasan et al., 2015)

The anticoccidiosis drug in rabbits is a relatively inexpensive medicine. However, there are several weaknesses, such as the fecal excretion which still may pollute the environment, especially when utilized as a fertilizer. Anticocidiosis drug is also absorbed and retained within the meat that results in resistance to the anticoccidiosis drugs for those who consume the rabbit meat. Unwisely and irrationally use of antibiotics may trigger the antimicrobial resistance (AMR) (Pakandl, 2009). Alternative approaches to control coccidiosis by medicinal plants extracts have promising prospects for anticoccidiosis agents (Ogbu and Onuh,2015; Abbas et al 2017). For example, the development of herbal plants as the natural coccidiostat is necessary to be conducted since those herbals may provide great opportunities for Indonesian regions with the tropical climate which is rich in natural resources.

Garlic (Allium sativum) is considered as one of the most essential and useful herbs used for medicinal purposes (Adulugba et al, 2017). Garlic can be used as antibacterial (Tipu et al., 2002; Safithri et al, 2011), antiparasitic, and anticoccidial agents in sheep (Worku, 2009) and chickens (Pourali et al., 2014; El-Khtam et al., 2014). Garlic and its sulfur compounds, allicin, aliin, ajoene, diallyl sulfide, dithiin, and allylcysteine are reported to have broad antimicrobial activities which can eliminate the negative factor of microbial infections. In vitro study in chicken shows that allicin inhibits sporulation of Eimeria tenella (Muthamilselvan et al, 2016).

In rabbits, garlic administration may reduce the number of the oocysts in rabbits which are infected with the hepatic coccidia (Toulah and Al-Raw, 2007; Abu-Akkada et al., 2010). Blood is one of physiological parameters used to determine the health of livestock animals. Garlic extract administration may prevent anemia in sheep which are infected by the coccidia (Worku et al., 2009). Research conducted on coccidiosis in rabbits is still very rare in Indonesia. Thus, this research aims at determining the influence of garlic extract on the excretion of oocysts either in vitro or in vivo on the hematological profile of the coccidian-infected rabbits.

\section{MATERIALS AND METHODS}

The research materials consisted of garlic (Allium sativum), oocysts of Eimeria stiedai, post weaning male rabbits (3 months of age, cross Rex breed, with average body weigt of $600 \mathrm{~g}$ ) that naturally infected with coccidia. The equipment and materials were required for oocyst sporulation, fecal examination, macerately produced garlic extract, and cultivation of rabbits during the research period. This research was approved by Research and Public Service Institution as well as Animal Science Faculty of Jenderal Soedirman University, Purwokerto. The research was conducted at the Livestock Health Laboratory of Jenderal Soedirman University (Unsoed), Research Laboratory of Unsoed, Experimental Farm of Unsoed, and in collaboration with the Animal Health Laboratory Type B of Central Java Province in Purwokerto.

\section{Preparation of Garlic Extract}

Preparation of garlic extractwas conducted with a maceration method using $70 \%$ of ethanol solvent. Two kilograms of garlic were thinly sliced and dried using a dryer with a temperature of $55-60^{\circ} \mathrm{C}$ for 4 days. The dried garlic was then crushed using a grinder to turn it into a powder. Each 100 gram of the garlic powder was subsequently immersed within 1 liter of $70 \%$ of ethanol solvent for 24 hours and then filtered. The rest fixing bath was re-filtered with $500 \mathrm{~g}$ of solvent for 24 hours. The filtrate was evaporated using a rotary evaporator. The extract was further evaporated in a waterbath to produce a concentrated extract. The concentrated extract was then stored at the temperature of $5^{\circ} \mathrm{C}$ and ready to use (Islam et al., 2008; Iqbal et al., 2013; Indrasanti et al., 2015).

\section{Preparation of Eimeria stiedai Isolates}

The propagation of E. stiedai isolates was conducted in vivo by orally infecting E. stiedai at a dose of $10^{3}$ in 5 post-weaning cross Rex breed rabbits. The experimental rabbits used were at the age of 3 months with the body weight of $\pm 600 \mathrm{~g}$ and free of coccidiosis. The feces was collected and examined using Whitlock method with the floating test and then the oocysts were calculated using Mc. Master method. In the isolate, $2 \%$ of potassium dichromate $\left(\mathrm{K}_{2} \mathrm{Cr}_{2} \mathrm{O}_{7}\right)$ was added and washed 3 times using the distilled water. The calculated oocysts were equal to 5000 opg (Coudert et al., 1993).

\section{In Vitro Mixing of Garlic Extract with E. stiedai Oocysts}

The 5000 opgs of oocysts were mixed with $0.5 \%$ of Na CMC (Natrium Carboxy Methyl Cellulose) and garlic extract with the concentration of $0 \mathrm{mg}$ per $100 \mathrm{~mL}$ (0\%), $1 \mathrm{mg}$ per $100 \mathrm{~mL}(1 \%), 2 \mathrm{mg}$ per $100 \mathrm{~mL}(2 \%), 4$ $\mathrm{mg}$ per $100 \mathrm{~mL}(4 \%), 8 \mathrm{mg}$ per $100 \mathrm{~mL}(8 \%)$, and then added with distilled water up to $15 \mathrm{~mL}$. The positive control used was Coxy ${ }^{\circledR}$ (sulfaquinoxalline). The incubation was conducted for 3 days at $26^{\circ} \mathrm{C}$ (Coudert et al., 
1993). The calculated oocysts covered the quantity of the sporulated, unsporulated, and abnormal oocysts after incubation.

\section{Preparation of Experimental Rabbits for in Vivo Study}

The experimental animals were naturally infected rabbits. The feces of the experimental rabbits was taken before the treatment to know the amount of rabbits using Whitlock method with the floating test. On the 21st day after treatment, blood samples were taken trough auricularis vena or cor $3 \mathrm{~mL}$.

\section{Administration of Garlic Extract to Experimental Rabbits}

The garlic extract with various dosages were orally administered once a day for 3 days, 2 resting days, and 3 re-medical administration days. Meanwhile, aquaprim ${ }^{\circledR}$ was intramuscularly administered for 3 respective days. The doses of garlic extract administration were $0,10,20$, 40 , and $80 \mathrm{mg} / \mathrm{rabbit}$ and the aquaprim ${ }^{\circledR}$ (per $\mathrm{mL}$ contains $200 \mathrm{mg}$ sulfadiazine and $40 \mathrm{mg}$ trimethoprim) was used as a positive control administered at $0.1 \mathrm{~mL} / \mathrm{kg}$ BW for 3 respective days. Feces examination was conducted before and 21 days after treatment. Blood collection was made on day 21.

\section{Experimental Design and Analysis}

The experiment was arranged in a Completely Randomized Design and the data collected were analyzed with the analysis of variance followed by further Honestly Significant Difference Test (Steel and Torrie, 1980). Phytochemical and proximate analyses of garlic powder were also respectively conducted at Indonesian Spice and Medicinal Crops Research Institute and Animal Feed Material Laboratory, Faculty of Animal Sciences, Jenderal Soedirman University. The hematological analyses covering the erythrocytes, hemoglobin, hematocrits, MCV, MCH, MCHC, and thrombocytes were conducted at Biofit in Purwokerto by The Sysmex XP-100 automated hematology analyzer (Ike et al., 2010; Karem et al, 2016).

\section{RESULTS}

\section{In Vitro Observation of Garlic Extract Effect on Oocysts}

The effectivity test of garlic extract on Eimeria stiedai oocyst sporulation isolated from the naturally infected rabbits was conducted in vitro. Parameters observed were the number of sporulated, unsporulated, and abnormal oocysts during 3 days incubation period. A root transformation was also conducted on the data shown in Table 1.

The number of the sporulated and unsporulated oocysts are presented in Figure 1. The highest number of abnormal oocysts was found in the treatment of administration of garlic extract at a dose of $4 \%$. The number of abnormal oocysts may be seen in Figure 2.

The result of variance analysis showed that the administration of garlic extract significantly decreased $(\mathrm{P}<0.01)$ the number of the sporulated and unsporulated oocysts $(\mathrm{P}<0.05)$, yet did not significantly influence the number of abnormal oocysts. In further test conducted with the honestly significant difference test showed that the administration of $4 \%$ of garlic extract was the most significant dose to decrease the number of sporulated oocysts among the doses of garlic extract used $(0 \%)$ and standard coccidiodstat of sulfaquinoxalline.

\section{The Phytochemical Test}

Qualitative phytochemical tests were conducted on saponin, tannin, alkaloid, phenolic, flavonoid, triterpenoid, steroid, and glycoside, while the quantitative tests were conducted on tannin, flavonoid, and saponin. The results of nutrient composition and phytochemical compound on garlic powder are shown in Table 2 and Table 3.

\section{Observation on Hematological Profiles of the Experimental Rabbits}

In this study, the hematological profile of rabbits infected with the widely open coccidia with various doses of garlic extract administration included the

Table 1. The number of sporulated, unprorulated, and transformed oocysts inclubated for 3 days with the administration of various doses of garlic extract

\begin{tabular}{lcccccc}
\hline \multirow{2}{*}{ Variables } & \multicolumn{9}{c}{ Treatments } \\
\cline { 2 - 7 } & A0 & A1 & A2 & A3 & A4 & A5 \\
\hline Sporulation & $11.18^{\mathrm{a}}$ & $10.32^{\mathrm{a}}$ & $10.13^{\mathrm{a}}$ & $6.08^{\mathrm{b}}$ & $10.47^{\mathrm{a}}$ & $9.85^{\mathrm{ab}}$ \\
No Sporulation & $6.01^{\mathrm{a}}$ & $4.42^{\mathrm{a}}$ & $2.97^{\mathrm{b}}$ & $2.83^{\mathrm{b}}$ & $1.98^{\mathrm{b}}$ & $3.78^{\mathrm{a}}$ \\
Abnormal & 0.71 & 4.06 & 3.27 & 4.15 & 3.18 & 2.92 \\
\hline
\end{tabular}

Note: A0: Eimeria stiedai oocysts with the administration of garlic extract at a dose of $0 \mathrm{mg}$ per $100 \mathrm{~mL}(0 \%)$, A1: Eimeria stiedai oocysts with the administration of garlic extract at a dose of $1 \mathrm{mg}$ per $100 \mathrm{~mL}(1 \%)$ to the cossidia-infected rabbits, A2: Eimeria stiedai oocysts with the administration of garlic extract at a dose of $20 \mathrm{mg}$ per $100 \mathrm{~mL} \mathrm{(2 \% )}$ to the coccidia-infected rabbits, A3: Eimeria stiedai oocysts with the administration of garlic extract at a dose of $40 \mathrm{mg}$ per $100 \mathrm{~mL}(4 \%)$ to the coccidia-infected rabbits, A4: Eimeria stiedai oocysts with the administration of garlic extract at a dose of $80 \mathrm{mg}$ per $100 \mathrm{~mL}(8 \%)$ to the coccidia-infected rabbits, and A5: medical control, coccidia-infected rabbits administered with Coxy (sulfaquinoxalline $1 \mathrm{~g}$ ). The same number was not significantly different in Honestly Significant Difference $5 \%$ 


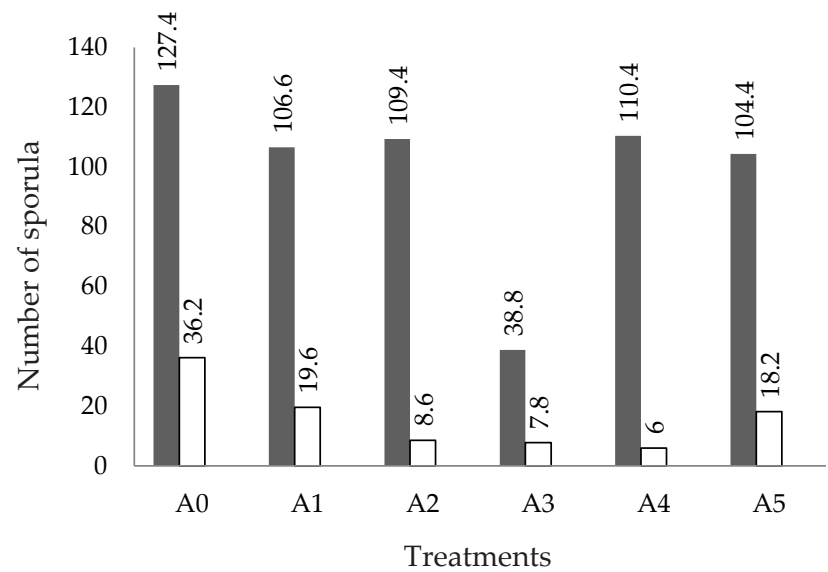

Figure 1. The numbers of the sporulated ( $\mathbf{m}$ ) and unsporulated () oocysts due to the various dosages of garlic extract administration. A0: Eimeria stiedai oocysts with the administration of garlic extract at a dose of $0 \%$, A1: Eimeria stiedai oocysts with the administration of garlic extract at a dose of $1 \%$ to the coccidia-infected rabbits, A2: Eimeria stiedai oocysts with the administration of garlic extract at a dose of $2 \%$ to the coccidiainfected rabbits, A3: Eimeria stiedai oocysts with the administration of garlic extract at a dose of $4 \%$ to the coccidia-infected rabbits, A4: Eimeria stiedai oocysts with the administration of garlic extract at a dose of $8 \%$ to the coccidia-infected rabbits, and A5: medical control, coccidia-infected rabbits administered with sulfaquinoxalline.

Table 2. Nutrient compositions of garlic powder (\% DM)

\begin{tabular}{lc}
\hline Nutrient composition $(\%)$ & Percentage \\
\hline Dry matter & 94.03 \\
Ash & 3.53 \\
Ether extract & 1.06 \\
Crude fiber & 0.50 \\
Crude protein & 27.05 \\
Nitrogen Free Extract & 67.85 \\
\hline
\end{tabular}

measurement on erytrocytes, hemoglobin, hematocrit, Mean Corpuscular Volume (MCV), Mean Corpuscular Hemoglobin $(\mathrm{MCH})$, Mean Corpuscular Hemoglobin Concentration (MCHC), and thrombocytes. The average hematological profile are presented in Table 1.

The results of variance analysis showed that there was no significant difference in hematological parameters in experimental rabbits administered with different doses of garlic extract. It proved that the administration of various doses of garlic extract had no significant effects on the coccidiosis in infected rabbits. The research showed that the highest level of average thrombocytes was found in the rabbits administered with $20 \mathrm{mg}$ of garlic extract while the lowest level was found in the experimental rabbits administered with $0 \mathrm{mg}$ of garlic extract. The results of variance analysis showed that there was a significant increases $(\mathrm{P}<0.05)$ in thrombocyte number in all treatments. However, the levels of thrombocytes found in this experiment were still in the normal

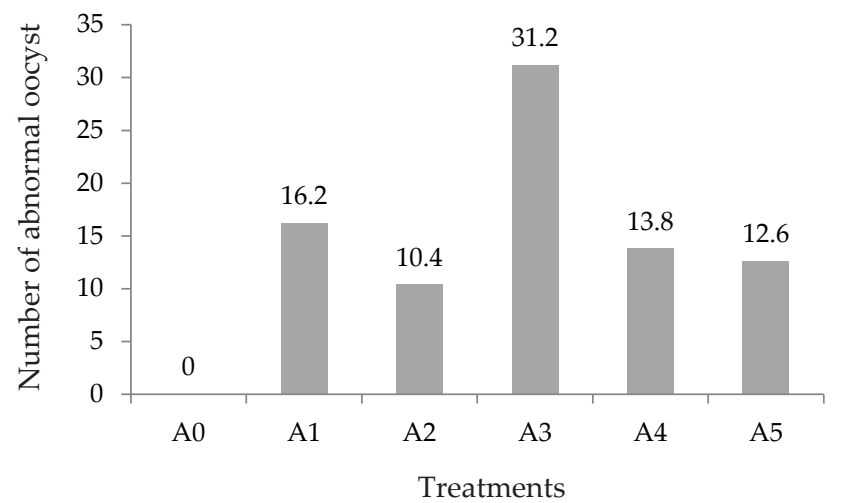

Figure 2. The number of abnormal oocysts on the administration of various dosages of garlic extract. A0: Eimeria stiedai oocysts with the administration of garlic extract at a dose of $0 \%$, A1: Eimeria stiedai oocysts with the administration of garlic extract at a dose of $1 \%$ to the coccidia-infected rabbits, A2: Eimeria stiedai oocysts with the administration of garlic extract at a dose of $2 \%$ to the coccidia-infected rabbits, A3: Eimeria stiedai oocysts with the administration of garlic extract at a dose of $4 \%$ to the coccidia-infected rabbits, A4: Eimeria stiedai oocysts with the administration of garlic extract at a dose of $8 \%$ to the coccidia-infected rabbits, and A5: medical control, coccidia-infected rabbits administered with sulfaquinoxalline.

Table 3. Phytochemical compounds of garlic powder

\begin{tabular}{ll}
\hline \multicolumn{1}{c}{ Compounds } & \\
\hline Saponin & + \\
Tannin & + \\
Alkaloid & + \\
Phenolic & - \\
Flavonoid & + \\
Triterpenoid & - \\
Steroid & - \\
Glycoside & - \\
\hline
\end{tabular}

Note: + = detected; - = not detected.

range. The Honestly Significant Difference Further Test showed that the administration of garlic extract at a dose of $20 \mathrm{mg}$ gave the most significant increase in thrombocyte level when compared to the other treatments. The administration of garlic extract at a dose of $80 \mathrm{mg}$ showed higher average results of hematological parameters (except thrombocyte) compared to the other treatments.

\section{DISCUSSION}

The administration of garlic extract at doses of $2 \%, 4 \%$, and $8 \%$ showed significantly different influences when compared to the other treatment with the administration of $0 \%$ of garlic extract and control 
Table 4. The hematological profile of coccidia-infected rabbits after administration with various dosages of garlic extract

\begin{tabular}{|c|c|c|c|c|c|c|c|c|}
\hline \multirow{3}{*}{$\frac{\text { Variables }}{\text { RBC }\left(\times 10^{6} / \mu \mathrm{L}\right)}$} & \multicolumn{8}{|c|}{ Treatments } \\
\hline & D0 & D1 & \multicolumn{2}{|c|}{ D2 } & \multicolumn{2}{|c|}{ D3 } & D4 & D5 \\
\hline & $4.48 \pm 0.47$ & $4.97 \pm 0.62$ & $4.05 \pm$ & 1.20 & $4.43 \pm$ & 0.71 & $5.11 \pm 1.33$ & $5.10 \pm 0.29$ \\
\hline HGB (g/dl) & $11.20 \pm 0.57$ & $10.80 \pm \quad 0.78$ & $9.60 \pm$ & 2.36 & $10.18 \pm$ & 1.76 & $11.80 \pm \quad 2.40$ & $11.24 \pm 0.67$ \\
\hline HCT (\%) & $35.58 \pm 1.75$ & $34.98 \pm 2.48$ & $31.32 \pm$ & 7.64 & $32.88 \pm$ & 4.68 & $37.14 \pm \quad 6.31$ & $35.04 \pm 2.15$ \\
\hline $\operatorname{MCV}(\mathrm{fl})$ & $76.60 \pm 7.59$ & $62.12 \pm 24.74$ & $79.48 \pm$ & 13.88 & $74.86 \pm$ & 8.09 & $74.62 \pm 10.22$ & $68.74 \pm 3.11$ \\
\hline $\mathrm{MCH}(\mathrm{pg})$ & $23.64 \pm 1.38$ & $21.90 \pm 2.44$ & $24.22 \pm$ & 3.58 & $23.04 \pm$ & 1.52 & $23.44 \pm$ & $22.04 \pm 0.66$ \\
\hline $\mathrm{MCHC}(\%)$ & $31.04 \pm 1.34$ & $30.88 \pm \quad 0.83$ & $30.62 \pm$ & 0.90 & $30.88 \pm$ & 2.67 & $31.62 \pm \quad 1.90$ & $32.06 \pm 0.68$ \\
\hline $\operatorname{PLT}\left(\times 10^{3} / \mu \mathrm{L}\right)$ & $298.20 \pm 54.44^{b}$ & $317.20 \pm 145.67^{\mathrm{ab}}$ & $566.80 \pm 1$ & $143.07^{a}$ & $509.20 \pm$ & $53.74^{\mathrm{ab}}$ & $417.40 \pm 162.90^{\mathrm{ab}}$ & $352.00 \pm 92.95^{\mathrm{at}}$ \\
\hline
\end{tabular}

Note: D0: coccidian-infected rabbits without administration of garlic extract, D1: coccidia-infected rabbits administered with garlic extract at a dose of $10 \mathrm{mg}$, D2: coccidia-infected rabbits administered with garlic extract at a dose of $20 \mathrm{mg}$, D3: coccidia-infected rabbits administered with garlic extract at a dose of $40 \mathrm{mg}$, D4: coccidia-infected rabbits administered with garlic extract at a dose of $80 \mathrm{mg}$, D5: coccidia-infected rabbits administered with aquaprim at a dose of $0.1 \mathrm{~mL} / \mathrm{kg}$ body weight. Means with the same superscript were not significantly different in Honestly Significant Difference 5\%. RBC: red blood cells (erythrocytes), HGB: hemoglobin, HCT: hematocrit, PLT: platelets; thrombocytes, MCV: mean corpurcular volume, $\mathrm{MCH}$ : mean corpurcular hemoglobin, MCHC: mean corpuscular hemoglobin concentration.

sulfaquinoxalline. In in vitro study, E. stiedai oocysts were incubated for 72 hours ( 3 days) to ensure that the oocysts were completely sporulated. The lowest average number of sporulated oocysts was found in the experimental oocyst administered with $4 \%$ of garlic extract, while the highest number of the unsporulated oocysts was found in the oocyst administered with $0 \%$ of garlic extract. The administration of garlic extracts to E. stiedai oocysts infecting the rabbits might provide influences by inhibiting the sporulation of oocysts and production of abnormal oocysts which are probably due to the anticoccidiosis effect of garlic active substance. The active substances contained in garlic extract might greatly be responsible for the anticoccidia activities.

Proximate analysis on garlic powder was conducted to determine the number of substances in order to identify the nutrient of a food substance contained in the feed materials. The results of proximate analysis showed that the protein level was high, in which protein has an important role for growth. High protein contained in feed materials requires further study whether garlic may be used as the substance administered in the rabbit ration to improve its performance and as a controlling agent against coccidiosis. The phytochemical qualitative test showed that garlic contained saponin, tannin, alkaloid, and flavonoid. Meanwhile, the phytochemical quantitative test on garlic powder to saponin was by $0.56 \%$, tannin by $0.73 \%$, and flavonoid by $0.46 \%$. This in vitro study conducted on garlic supported the previous research that garlic might be used as antcoccidiosis. Garlic has several active compounds including allicin, alliin, ajoene, diallyl sulfide, dithiin, and allylcystein, in which allicin may inhibit E. tenella sporulation in chickens (El-Khtam et al., 2014; Pourali et al., 2014). The other natural plant functioning as an anticoccidiosis is banana stem. Our previous in vitro test showed that banana stem extract might decrease E. stiedai oocysts (Indrasanti et al., 2015). The existing tannin contained in garlic and banana stem, as contained in pine stem extract, might significantly decrease the oocyst sporulation ability by inhibiting the enzyme activity contributing in the sporulation process, by penetrating through the oocystic cell walls and destroying the cytoplasm (sporont) that resulted in abnormal oocysts (Molan et al., 2009; Indrasanti et al., 2015).

The normal standard of erythrocytes count, hemoglobin, hematocrit, mean corpurcular volume (MCV), mean corpurcular hemoglobin $(\mathrm{MCH})$, mean corpuscular hemoglobin concentration (MCHC), and thrombocytes are $6.24 \pm 0.24 \times 10^{6} / \mu \mathrm{L}, 13.4 \pm 0.5 \mathrm{~g} / \mathrm{dL}, 42.5 \pm 1.6 \%$, $68.1 \pm 1.9 \mathrm{fL}, 21.5 \pm 0.6 \mathrm{pg}, 31.4 \pm 0.9 \%$, and $200-1000 \times 10^{3} /$ $\mu \mathrm{L}$, respectively (Weiss \& Wardrop, 2010). The research showed that the highest average of erythrocytes, hemoglobin, and hematocrite were at the administration of 80 $\mathrm{mg}$ of garlic extract, while the lowest levels were found at the administration of $20 \mathrm{mg}$ of garlic extract. The highest average of MCV level was found in the experimental rabbits administered with garlic extract at a dose of $20 \mathrm{mg}$ while the lowest was found in the experimental rabbits administered with garlic extract at a dose of 10 $\mathrm{mg}$. The highest average of $\mathrm{MCH}$ level was found in the experimental rabbits administered with garlic extract at a dose of $20 \mathrm{mg}$ while the lowest was found in the experimental rabbits administered with aquaprime. The highest average of MCHC level was found in the experimental rabbits administered with aquaprim while the lowest level was found in the experimental rabbits without administration of garlic extract $(0 \mathrm{mg})$.

Akhtar et al. (2012) stated that infection of coccidia might influence the whole hematological parameters. The hematological changes on the coccidia-infected rabbits were proven with the significantly decreasing number of erythrocytes, hemoglobin, and hematocrit as well as the increasing number of leukocytes, especially eosinophils, and neutrophils (Al-Saeed et al., 2017). In the present experiment, the whole experimental rabbits still suffered from anemia, in which all erythrocytes, hemoglobin, and hematocrit numbers were below the normal standard levels although they had been administered with the garlic extract during the treatments. However, only thrombocytes $(\mathrm{P}<0.05)$ and leukocytes that showed significant increases $(\mathrm{P}<0.01)$, but without correlation with the increasing doses of garlic extract administration. In addition, the number of oocyst in rab- 
bits treated with banana stem extract decreased significantly $(\mathrm{P}<0.01)$ as published in our previous research.

The clinical symptoms of the coccidian-infected rabbits were depression, anorexia, brown watery diarrhea, weakness, coarse hair, hardening of abdomen, and continuously thinning (Al-Saeed et al., 2017). In the present research, the rabbits had the possibility of undergoing a subclinical coccidiosis that most rabbits in Banyumas Regency were sub-clinically infected, in which the clinical symptoms were not clearly visible, yet due to the hematological profile, there was anemia.

In the present research, the administration of garlic extract as the treatments for those coccidia-infected rabbits was indirectly unable to overcome the anemic problems. Thus, further researches on the administration of garlic extract in feed to control coccidiosis in rabbit should be conducted as well as to strengthen the statement of Abu-Akkada et al. (2010) who explained that oral administration of crude garlic was effective for reducing the excretion of oocysts and might increase the body weight of the hepatic coccidia-infected rabbits. ElKhtam et al. (2014) also described that garlic and turmeric powder as one of animal feed supplements was effective for the treatment of coccidiosis. Similarly, Nosal et al. (2016) stated that garlic and oregano administration in animal feed might function as the prophylaxis, in case of the sub-clinically coccidia-infected rabbits. Toulah and Al-Raw (2007) also stated that the administration of crude garlic before the coccidia infection might reduce the excretion of oocysts more effectively as a prophylaxis than as a medication.

Effectiveness of the garlic extract on prevention of coccidiosis is related to the bioactive compound of garlic. Garlic is rich in organosulfur compounds (OSC) whose precursors (allicin, diallyl sulfide, and diallyl trisulfide are believed to play key roles in antioxidant and anti-inflammatory effects (Pourali et al, 2014). Therefore, in the present experiment, garlic probably eliminated the negative effect of coccidial infection in the experimental rabbits. The anticocidial mechanism of garlic and its sulfur compounds remains elusive. However, one of phytochemicals that interferes with life cycle of Eimeria $s p$ is allicin that inhibits the development of sporozoites Eimeria spp. Whereas, propyl thiosulfinate can be beneficial as a immunity protector (Muthamilselvan et al, 2016).

\section{CONCLUSION}

In vitro analysis showed that the administration of garlic extract might decrease the excretion number of oocysts at the dosage of $20 \mathrm{mg}$ and influenced some hematological parameters in in vivo. This research provided new hope for the natural coccidiosis control in rabbits.

\section{ACKNOWLEDGEMENT}

All authors expressed appreciation to University of Jenderal Soedirman for financial support through Hibah Riset Institusional, BLU Unsoed 2016.

\section{REFERENCES}

Abbas A., Z. Iqbal, R. Z. Abbas, M. K. Khan, \& J. A. Khan. 2017. Immunomodulatory activity of Pinus radiata extract against coccidiosis in broiler chicken. Pak. Vet. J. 37: 145-149.

Abbas R. Z., Z. Iqbal, M.N. Khan, M. A. Zafar, \& M. A. Zia. 2010. Anticoccidial activity of Curcuma longa L. in broilers. Braz. Arch. Biol. Technol. 53:63-7. https://doi.org/10.1590/ S1516-89132010000100008

Abu-Akkada S. S., S.O. Samah, \& K.I. Ashmawy. 2010. Garlic and hepatic coccidiosis: prophylaxis or treatment? Trop. Anim. Health Prod. 42:1337-1343. https://doi.org/10.1007/ s11250-010-9590-6

Adulugba I.A., O.N. Goselle, O.O. Ajayi, \& J.T. Tanko. 2017. Development of a potent anti-coccidial drug: A phyto-synthetic approach. Am. J. Phytomedicine Clin. Ther. 1:1-7.

Akhtar, M., A. F. Tariq, M. M. Awais, Z. Iqbal, F. Muhammad, M. Shahid, \& E. Hiszczynska-Sawicka. 2012. Studies on wheat bran Arabinoxylan for its immunostimulatory and protective effects against avian coccidiosis. Carbohydr. Polym. 90: 333-339. https://doi.org/10.1016/j. carbpol.2012.05.048

Al-Saeed M. H., A.H. Al Saeed, \& M. M. Jori. 2017. Study of physiological and histological changes in rabbits induced with hepatic coccidiosis. Journal University of Kerbala 15:217-228.

Coudert P, L. Licois, \& F. Drouet-Viard. 1995. Eimeria Species And Strain of Rabbits. In: Biotechnology, Guidelines on Techniques in Coccidiosis Research. European Commision. Luxembroug. Pp:52-73.

El-Khtam A. O., A. A. El-Latif, \& M. H. El-Hewaity. 2014 Efficiency of turmeric (Curcuma longa) and garlic (Allium sativum) on Eimeria species in broilers. Int. J. Basic Appl. Sci. 3:349-356.

Ike, S. O., T. Nubila, E. O. Ukaejiofo, I. N. Nubila, E. N. Shu, \& I. Ezema. 2010. Comparison of haematological parameters determined by the Sysmex KX - 2IN automated haematology analyzer and the manual counts. BMC Clin. Pathol. 10: 1-5. https://doi.org/10.1186/1472-6890-10-3

Indrasanti D., M. Indradji, S. Hastuti, H. Wihadmadyatami, \& Ismoyowati. 2015. The efficacies of banana stem extract as a candidate of coccidiostat against rabbit Eimeria stiedai oocysts: An in vitro analysis. Animal Production. 17:161-168. https://doi.org/10.20884/1.anprod.2015.17.3.503

Iqbal A., K. A. Tariq, V. S. Wazir, \& R. Singh. 2013. Antiparasitic efficacy of Artemisia absinthium, toltrazuril and amprolium against intestinal coccidisosis in goats. J. Parasit Dis. 37:88-93.

Islam K. R., T. Farjana, N. Begum, \& M.M.M. Mondal. 2008. In vitro efficacy of some indegenous plants on the inhibition of development of eggs of Ascaridia galli (digenia: nematoda). Bangl. J. Vet. Med. 6:159- 167.

Karem K. K., A. N. Sabour, \& B. M. Kulaif. 2016. Comparison between manual procedure and automated for determinant of WBCs and PCV in maternity and labor hospital in Karbala City. J. Contemp. Med. Sci. 2: 93-95.

Molan A. L., Z. Liu, \& S. De. 2009. Effect of pine bark (Pinus radiata) extract on sporulation of coccidian oocysts. Folia Parasitol. 56: 1-5. https://doi.org/10.14411/fp.2009.001

Muthamilselvan, T., T. Kuo, W. Yang, \& W. Yang. 2016. Herbal remedies for coccidiosis control: A review of plants, compouns, anticoccidial actions. Evid. Based Complement. Alternat. Med. 2016:1-19. https://doi. org/10.1155/2016/2657981

Nistor E., V. A. Bampidis, N. Pacala, M. Pentea, J. Tozer, \& Prundeanu. 2013. Nutrient content of rabbit meat as compared to chicken, beef and pork meat. J. Anim. Prod. Adv. 
3:172-176. https://doi.org/10.5455/japa.20130411110313

Nosal P., D. Kowalska, P. Bielanski, J. Korwal, \& S. Kornas. 2016. Herbal formulations as feed additives in the course of rabbi subclinical coccidiosis. Ann. Parasitol. 60:65-69.

Ogbu C. C. \& S. S. Onuh. 2015. Oocyst output, performance and haematological indices of broiler chickens infected with coccidian oocysts and fed Ocimum gratissimum leaf extract. Glob. J. Poult. Farm. Vaccin. 3:146-153.

Pakandl, M. 2009. Coccidia of rabbit: A Review. Folia Parasitol. 56:153-166. https://doi.org/10.14411/fp.2009.019

Pourali M., H. Kermanshahi, A. Golian,G. R. Razmi, \& M. Soukhtanloo. 2014. Antioxidant and anticoccidial effects of garlic powder and sulfur amino acids on Eimeriainfected and uninfected broiler chickens. IJVR. 15:227-232.

Tipu M. A., T. N. Pasha, \& Z. Ali. 2002. Comparative efficacy of salinomycin sodium and Neem fruit (Azadiracht indica) as feed additive anticoccidials in broilers. Int. J. Poult. Sci. 1:91-93. https://doi.org/10.3923/ijps.2002.91.93

Toulah F. H. \& M. M. Al-Raw. 2007. Efficacy of garlic extract on hepatic coccidiosis in infected rabbits (Oryctolagus cuniculus): histological and biochemical studies. J. Egypt. Soc Parasitol. 37:957-968.

Savithri, M., M. Bintang, \& M. Poeloengan. 2011. Antibacterial Activity of Garlic Extract Against some Pathogenic Animal Bacteria. Med. Pet. 34: 155-158. https://doi.org/10.5398/ medpet.2011.34.3.155

Srinivasan H., A. Thangavel, S. Balakrishnan, S. Duraisamy, \& S. Muthusamy. 2015. In vivo anticoccidial effects of Azadirachta indica and Carica papaya L. with salinomycin drug as a dietary feed supplement in broiler chicks. Pak. J. Pharm. Sci. 28: 1409-1415.

Steel R. G. D. and J. H. Torrie. 1980. Principles and Procedures of Statistics. McGraw-Hill Book Company, New York.

Weiss D. J. \& K. J. Wardrop. 2010. Schalm's Veterinary Hematology. 6th Ed. Wiley and Blackwell Publishing, USA. Pp:852-879.

Worku M., R. Franco, \& K. Baldwin. 2009. Efficacy of garlic as an anthelmintic in adult boer goats. Arch. Biol. Sci. 61:135140. https://doi.org/10.2298/ABS0901135W 